\title{
BMJ Global Health Income security in times of ill health: the next frontier for the SDGs
}

\author{
Knut Lönnroth (D) , ${ }^{1}$ Lou Tessier, ${ }^{2}$ Gunnel Hensing, ${ }^{3}$ Christina Behrendt ${ }^{2}$
}

\begin{abstract}
To cite: Lönnroth $\mathrm{K}$, Tessier $\mathrm{L}$, Hensing G, et al. Income security in times of ill health: the next frontier for the SDGs. BMJ Global Health 2020;5:e002493. doi:10.1136/ bmjgh-2020-002493
\end{abstract}

Handling editor Seye Abimbola

Received 14 March 2020 Revised 22 April 2020 Accepted 23 April 2020

\section{SLinked}

- http://dx.doi.org/10.1136/ bmjgh-2020-002425

- http://dx.doi.org/10.1136/ bmjgh-2020-002504

- http://dx.doi.org/10.1136/ bmjgh-2019-002172

Check for updates

(C) Author(s) (or their employer(s)) 2020. Re-use permitted under CC BY-NC. No commercial re-use. See rights and permissions. Published by BMJ.

${ }^{1}$ Department of Global Public Health, Karolinska Institute, Stockholm, Sweden

${ }^{2}$ Social Protection Department, International Labour Organization, Geneve, Switzerland

${ }^{3}$ School of Public Health and Community Medicine, Institute of Medicine, Sahlgrenska Academy, University of Gothenburg, Goteborg, Sweden

Correspondence to Professor Knut Lönnroth; knut.Ionnroth@ki.se

\section{INTRODUCTION}

Poor health can trap individuals, families and communities in a vicious disease-poverty cycle. While ensuring universal access to affordable healthcare in times of need is essential to break this cycle, income security in time of sickness or injury for all is equally important. Recent evidence indicates that people who cannot work or are not allowed to work due to illness face high indirect costs linked to income loss, which can be compounded by the opportunity cost of time spent seeking and staying in care. For example, the ongoing Covid-19 pandemic illustrates that lack of income security leads to economic hardship for individuals and creates barriers for adhering to infection control measures, ${ }^{12}$ and similar challenges have previously been well-documented concerning tuberculosis. ${ }^{3}$

Both access to healthcare services and income security in case of illness are enshrined in the human rights to health and social security and in international standards on social protection. ${ }^{45}$ Income security acts on both the social determinants and the adverse consequences of ill health. The provision of sickness benefits is the primary responsibility of the State, usually implemented by social protection institutions under the joint stewardship of the health, social and labour sectors. Yet, while access to healthcare services is at the forefront of the 2030 Agenda through a dedicated Target on Universal Health Coverage (UHC), income security in case of ill health has limited visibility within the Sustainable Development Goals (SDGs) and is underresearched, especially in low-income and middle-income countries (LMICs). ${ }^{6}$

\section{UNPACKING SDG TARGETS AND INDICATORS}

The SDGs constitute an unprecedented opportunity to accelerate synergistic actions on health and social protection. Achieving the health Targets under Goal 3 will contribute to social well-being. Moreover, the UHC Target

\section{Summary box}

Universal health coverage (UHC) is at the forefront of the discussions on how to achieve the health-related Sustainable Development Goals (SDG).

- A prominent part of the UHC agenda is to ensure that people are not impoverished due to high healthcare expenditures. While this is crucial, it is not sufficient to protect people from hardship in times of ill health, as illustrated in the ongoing Covid-19 pandemic where lack of income security creates barriers for people to adhere to infection control measures.

- Social protection systems ensuring income security when unable to work due to sickness are as important as schemes designed to reduce out-of-pocket healthcare expenditure. Yet, this is not part of the UHC framework and not sufficiently visible in the SDG Target on social protection.

- This contrasts sharply with the high prioritisation of income security in times of ill health when universal social protection systems were built in the last century in many of today's high-income countries.

(3.8) has a specific indicator for financial protection (3.8.2), which measures occurrence of catastrophic out-of-pocket healthcare expenses. The focus is on direct medical costs while income security in times of ill health is not included. This was a conscious choice as the indicator measures what UHC intends to achieve: access to needed healthcare without financial hardship from paying for these services. ${ }^{7}$

SDG Target 1.3 on social protection aims to implement nationally appropriate social protection systems and measures for all, including floors. In principle, this scope includes income security in case of ill health. Still, this dimension is currently missing in the related monitoring indicator 1.3.1 ('Percentage of the population covered by social protection floors/systems') which reports social protection coverage for children, unemployment, old age, disability and work injury benefits, but not for sickness benefits. 8 
This exclusion directly correlates to a shortage of comparable data across countries. Indicators cannot capture all that is important of course, but they are an opportunity to set an accountability framework fostering the collection and publication of more and better data. In this respect, progress needs to be made. In line with the nine branches of social security defined under the International Labour Organization (ILO) Convention No. 102, the World Social Protection Database provides information on whether the legal framework includes entitlements to income support in case of sickness and collects national-level data on effective coverage for this contingency. Yet, more reporting is necessary to allow for the elaboration of global estimates. ${ }^{9}$

These challenges relate to the setup of such guarantees. Indeed, many countries chose to cover this contingency through an employer's liability (ie, there is no social protection scheme as such, each employer is responsible to continue to pay the worker's salary during sick leave). This model has two effects. First, this form of protection is often limited to those covered under national labour legislation while those in informal employment remain unprotected. Second, it can create a disincentive for employers to hire and retain workers from groups prone to sickness, as the full cost of sick leave falls on them. This is a concern for small and medium enterprises where resources can be limited. ${ }^{10}$ The labour force in LMICs is still largely informal. More efforts are necessary to extend social protection coverage, including income security in case of sickness, to those in informal employment and facilitate their transition to the formal economy, which also contributes to fostering decent work under Goal 8 and the broader SDG agenda.

\section{LEARNING FROM HISTORY}

Income security in times of ill health has been part of social protection systems in many high-income countries (HIC) for over half a century, often longer than universal access to healthcare. After a long period of heterogeneous and small-scale union-based or guild-based mutual funds, the first national legislations on social insurance came into force around the turn from the 18th to the 19 th century in countries that are today classified as HIC, but at the time had fiscal space that was no larger than today's poor countries. The 20th century saw scale-up in fits and starts towards universalism through periods of devastating wars and economic depression. ${ }^{11} 12$

The Bismarck and Beveridge models did not only concern health coverage as defined today under the UHC framework. They were models for comprehensive social health protection, including both access to healthcare without hardship and income security in times of sickness. ${ }^{13}$ One underpinning argument was that income security coupled with rehabilitation would help prevent permanent incapacity to work due to chronic conditions and hence reduce the burden on disability pension and poverty relief schemes. Another was that income security would facilitate implementation of infectious disease control measures. None of the early schemes had only healthcare benefits. In many countries, including Germany, UK and Sweden, sickness benefits came first, followed by gradual introduction of healthcare benefits. Lord Beveridge stated upfront in his 1942 report that UK had by then already made progress on social insurance, and argued that it was now time to include also healthcare coverage since 'a plan for social security assumes a concerted social policy in many fields'. ${ }^{14}$

The human rights framework and international labour standards followed this approach, considering income security in case of sickness an integral part of social health protection. ${ }^{5}$ As early as 1927, the ILO adopted the first convention on sickness benefits, which was subsequently included in the Social Security (Minimum Standards) Convention, 1952 (No. 102), the Medical Care and Sickness Benefits Convention, 1969 (No. 130) and Recommendation, 1969 (No. 134). Those instruments call on member states to set up systems ensuring protection in case of 'incapacity for work resulting from a morbid condition and involving suspension of earnings'. However, their global implementation was hampered by various factors, and the available data suggests effective coverage remains very low. ${ }^{15}$ In spite of the inclusion of income security during sickness in the Social Protection Floors Recommendation, 2012 (No. 202), the recent United Nations resolutions do not elaborate on $\mathrm{it}^{16}$ and more needs to be done to better reflect it in the SDG framework.

\section{MOVING FORWARD}

Despite the Universal Declaration of Human Rights including 'the right to security in the event of sickness' and WHO's definition of health as including 'social wellbeing', attention to income security in times of sickness remains limited in the global health field. A reason is perhaps that UHC and scientific advances are expected to solve the problem through swift cures for most conditions. Medical and allied science have advanced tremendously. Healthcare services can cure more diseases and reduce risk of long-term disability. Still, UHC will not eliminate the risk of income insecurity in case of sickness.

The global tuberculosis and HIV/AIDS strategies are ahead of the game. ${ }^{1718}$ They include policy commitments on social protection and monitoring tools. Heavily subsidised healthcare services have been scaled up globally for those diseases, which is probably why the limitations of affordable healthcare alone to prevent poverty effects of diseases have become obvious. Evidence indicates that patients who pay little out of pocket for quality healthcare still face high indirect costs. ${ }^{19}$ The national tuberculosis patients cost surveys coordinated by WHO show that patients experience variable levels of direct medical costs depending on the country context, but also high direct non-medical costs (mostly transport and nutrition) 
and income loss, creating additional incentives to forgo care. $^{319}$

There is good reason to believe that income security is an equally important global challenge for people with both communicable and non-communicable diseases, including diabetes, cancer, cardiovascular diseases and mental health problems. The long-term solution should not be disease-specific social protection schemes but universal systems that provide better ways to extend income security protection in case of sickness for all. Let's not wait until 2030 to put this issue firmly on the global health agenda and in the discussions on the future of social protection. ${ }^{20}$

Acknowledgements All authors are members of the Health and Social Protection Action Research \& Knowledge Sharing network (SPARKS), an international interdisciplinary research network. SPARKS' multi-sectoral team characterizes and evaluates the direct and indirect effects of social protection strategies on health, economic, and wider outcomes.

Contributors All authors conceptualised the paper, wrote it jointly and approved the final version.

Funding Funding was received from the Swedish Research Council (2018-05174). Competing interests None declared.

Patient consent for publication Not required.

Provenance and peer review Not commissioned; externally peer reviewed.

Data availability statement No additional data are available.

Open access This is an open access article distributed in accordance with the Creative Commons Attribution Non Commercial (CC BY-NC 4.0) license, which permits others to distribute, remix, adapt, build upon this work non-commercially, and license their derivative works on different terms, provided the original work is properly cited, appropriate credit is given, any changes made indicated, and the use is non-commercial. See: http://creativecommons.org/licenses/by-nc/4.0/.

ORCID iD

Knut Lönnroth http://orcid.org/0000-0001-6944-0256

\section{REFERENCES}

1 Tran PT, Hensing G, Thorpe J, et al. Income security during public health emergencies: the novel coronavirus (COVID-19) poverty trap in Vietnam. BMJ Global health 2020.

2 ILO. Social protection response to the COVID-19 crisis. Geneva: ILO, 2020. https://www.social-protection.org/gimi/ShowWiki.action?id= 62

3 WHO. Global tuberculosis report 2018 [Internet. Geneva: WHO, 2018. https://apps.who.int/iris/bitstream/handle/10665/274453/ 9789241565646-eng.pdf
4 UN CESCR. General Comment No. 19: The right to social security [Internet. Geneva: United Nations Economic and Social Council: Committee on Economic, Social and Cultural Rights, 2008. http:// www.unhcr.org/refworld/type,GENERAL,,,47b17b5b39c,0.html

5 ILO. Towards universal health coverage: social health protection principles. social protection spotlight brief. Geneva: ILO, 2020. https://www.social-protection.org/gimi/RessourcePDF.action?id= 56009

6 Thorpe J, Viney K, Hensing G, et al. Income security during periods of ill-health: a scoping review of policies and practice in low- and middle-income countries. BMJ Global Health 2020.

7 WHO and World Bank. Tracking universal health coverage: 2017 global monitoring report, 2017. Available: https://apps.who.int/ iris/bitstream/handle/10665/259817/9789241513555-eng.pdf; jsessionid=ED792936448A1E92BC6A1E01F4A7C3EB?sequence=1 [Accessed 11 Nov 2019].

8 United Nations. Metadata for sustainable development goal 1, target 1.3, indicator 1.3.1. Available: https://unstats.un.org/sdgs/metadata/ files/Metadata-01-03-01a.pdf

9 ILO. World Social Protection Report 2017-19: Universal social protection to achieve the Sustainable Development Goals [Internet. Geneva: International Labour Office, 2017. http://www.socialprotection.org/gimi/gess/ShowWiki.action?id=594

10 Scheil-Adlung X. Can productivity in SMEs be increased by investing in workers' health? [Internet. Geneva: International Labour Office, 2014. https://www.social-protection.org/gimi/gess/RessourcePDF. action?ressource.ressourceld $=46357$

11 Edenbalk P. The emerging welfare state - Swedish social insurance 1884-1955. Lund, Arkiv Förlag, 1995.

12 Lindner U. Gesundheitspolitik in Der Nachkriegszeit: Grossbritannien und die Bundesrepublik Deutschland Im Vergleich. Oldenbourg Verlag, 2011.

13 Gorsky M, Sirrs C. The Rise and Fall of "Universal Health Coverage" as a Goal of International Health Politics, 1925-1952. Am J Public Health 2018;108:334-42.

14 Musgrove P. Health insurance: the influence of the Beveridge report. Bull World Health Organ 2000;78:845-6.

15 Scheil-Adlung X, Sandner L. Paid sick leave: Incidence, patterns and expenditure in times of crises [Internet. Geneva: International Labour Office, 2010. http://www.socialsecurityextension.org/gimi/gess/ RessFileDownload.do?ressourceld $=17463$

16 UN. Transforming our world: The 2030 Agenda for Sustainable Development, Resolution adopted by the General Assembly on 25 September 2015 [Internet]. New York: United Nations, 2015. Available: https://sustainabledevelopment.un.org/post2015/ transformingourworld

17 WHO. The End TB Strategy. Global strategy and targets for tuberculosis prevention, care and control after 2015. [Internet], 2014. Available: https://www.who.int/tb/strategy/en/ [Accessed 25 Feb 2020].

18 UNAIDS. Unaids strategy 2016-2021 - on the fast-track to end AIDS Geneva: UNAIDS, 2015.

19 Lönnroth K, Glaziou P, Weil D, et al. Beyond UHC: monitoring health and social protection coverage in the context of tuberculosis care and prevention. PLoS Med 2014;11:e1001693.

20 ILO. ILO Centenary Declaration for the Future of Work [Internet], 2019. Available: https://www.ilo.org/wcmsp5/groups/public/@ed norm/@relconf/documents/meetingdocument/wcms_711674.pdf 